\title{
Theoretical Knowledge of Nurses Working in Non-Hospital Urgent and Emergency Care Units Concerning Cardiopulmonary Arrest and Resuscitation
}

\author{
Angélica Olivetto de Almeida ${ }^{1}$ \\ Izilda Esmenia Muglia Araújo² \\ Maria Célia Barcellos Dalri ${ }^{3}$ \\ Sebastião Araujo ${ }^{4}$
}

\begin{abstract}
Non-Hospital Urgent and Emergency Care Units were created to deliver care to patients in chronic or acute situations and to coordinate the flow of urgent care. This descriptive study analyzed the theoretical knowledge of nurses working in these units concerning cardiopulmonary arrest and resuscitation. A questionnaire was applied to 73 nurses from 16 units in seven cities in the region of Campinas, SP, Brazil. The respondents displayed some gaps in their knowledge such as how to detect Cardiopulmonary Arrest (CPA), the ability to list the sequence of basic life support, and how to determine the appropriate compression to ventilation ratio $(>60 \%)$. They also did not know: the immediate procedures to take after CPA detection ( $>70 \%$ ); the rhythm pattern present in a CPA ( $>80 \%)$; and they only partially identified $(100 \%)$ the medication used in cardiopulmonary resuscitation. The average score on a scale from zero to ten was $5.2( \pm 1.4)$. The nurses presented partial knowledge of the guidelines available in the literature.
\end{abstract}

Descriptors: Heart Arrest; Knowledge; Nursing; Cardiopulmonary Resuscitation.

\footnotetext{
${ }^{1}$ RN, M.Sc. in Nursing, Hospital de Clínicas, Universidade Estadual de Campinas, SP, Brazil. E-mail: angelica@hc.unicamp.br.

${ }^{2}$ RN, Ph.D. in Nursing, Professor, Faculdade de Ciências Médicas, Universidade Estadual de Campinas, SP, Brazil. E-mail: iema@fcm.unicamp.br.

${ }^{3}$ RN, Ph.D. in Nursing, Professor, Escola de Enfermagem de Ribeirão Preto, Universidade de São Paulo, WHO Collaborating Centre for Nursing Research Development, SP, Brazil. E-mail: macdalri@eerp.usp.br.

${ }^{4}$ Physician, Professor, Faculdade de Ciências Médicas, Universidade Estadual de Campinas, SP, Brazil. E-mail: seba@fcm.unicamp.br.
} 


\title{
Conhecimento teórico dos enfermeiros sobre parada e ressuscitação cardiopulmonar, em unidades não hospitalares de atendimento à urgência e emergência
}

As unidades não hospitalares de atendimento à urgência e emergência foram criadas para atender pacientes com quadros agudos ou crônicos agudizados e ordenar os fluxos de urgência. O objetivo deste estudo foi analisar o conhecimento teórico dos enfermeiros dessas unidades, sobre parada cardiorrespiratória e ressuscitação cardiopulmonar. Este é um estudo descritivo, cujos dados foram obtidos pela aplicação de questionário a 73 enfermeiros de 16 unidades, de sete municípios da Região Metropolitana de Campinas. Observou-se que os entrevistados apresentaram lacunas de conhecimento sobre como detectar a parada cardiorrespiratória, a sequência do suporte básico de vida e a relação ventilação/compressão ( $>60 \%)$; desconhecem as condutas imediatas após detecção ( $>70 \%$ ) e os padrões de ritmos presentes na parada cardíaca ( $>80 \%$ ) e que identificaram parcialmente $(100 \%)$ os fármacos utilizados na ressuscitação cardiopulmonar. A nota média foi $5,2( \pm 1,4)$, em uma escala de zero a dez. Conclui-se que os enfermeiros apresentaram conhecimento parcial das diretrizes disponíveis na literatura.

Descritores: Parada Cardíaca; Conhecimento; Enfermagem; Ressuscitação Cardiopulmonar.

\section{Conocimiento teórico de los enfermeros sobre parada cardiorrespiratoria y resucitación cardiopulmonar en unidades no hospitalarias de atención de urgencia y emergencia}

\begin{abstract}
Las Unidades no hospitalarias de Atención de Urgencia y Emergencia fueron creadas para atender pacientes con cuadros agudos o crónicos agudos y ordenar los flujos de urgencia. El objetivo de este estudio fue analizar el conocimiento teórico de los enfermeros de esas unidades sobre parada cardiorrespiratoria y resucitación cardiopulmonar. Se trata de un estudio descriptivo, cuyos datos fueron obtenidos aplicando un cuestionario a 73 enfermeros de 16 unidades, de siete municipios de la Región Metropolitana de Campinas. Se observó que los entrevistados presentaron vacíos de conocimiento sobre como detectar: la parada cardiorrespiratoria, la secuencia del soporte básico de vida y la relación ventilación/compresión ( $>60 \%$ ); desconocen las conductas que deben adoptadas inmediatamente después de la detección (> 70\%) y los estándares de ritmos presentes en la parada cardíaca (> 80\%); y identificaron parcialmente $(100 \%)$ los fármacos utilizados en la resucitación cardiopulmonar. La nota promedio fue $5,2( \pm 1,4)$, en una escala de cero a diez. Se concluye que los enfermeros presentaron conocimiento parcial de las directrices disponibles en la literatura.
\end{abstract}

Descriptores: Paro Cardíaco; Conocimiento; Enfermería; Resucitación Cardiopulmonar.

\section{Introduction}

The Brazilian Ministry of Health (MH) established the National Policy on Emergency Care in 2002. Since demand for this service has risen in recent years in Brazil given increased violence and a larger number of accidents, the supply of urgent and emergency services has become insufficient ${ }^{(1)}$.

To meet such demand, the $\mathrm{MH}$ invested in pre- hospital care, regulation centers, and in the structure of urgent and emergency care networks. Therefore, nonhospital urgent and emergency care units (N-HUECU), previously called simply 'emergency care', emerged.

The teams in these N-HUECU should be prepared for urgent and emergency situations and nurses are those who should effectively care for more complex cases, 
including interventions for patients with Cardiopulmonary Arrest (CPA), initiating Basic Life Support (BLS) and aiding in Advanced Life Support (ALS). For health professionals to provide safe care and ensure the survival of patients, they need to be prepared and have knowledge concerning resuscitation techniques. Given these requirements, we examine what the theoretical knowledge of nurses working in $\mathrm{N}-\mathrm{HUECU}$ concerning this topic is.

The literature indicates that after CPA, survival varies from $2 \%$ to $49 \%$ depending on the initial cardiac rhythm and early initiation of resuscitation (2). Another study reports that the survival rate can double or triple when Cardiopulmonary Resuscitation (CPR) is properly

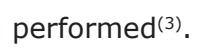

Considering the previous discussion, this study analyzes the theoretical knowledge of nurses working in $\mathrm{N}-\mathrm{HUECU}$ concerning CPR and CPA.

\section{Method}

This is a descriptive study with quantitative approach. The population comprised 91 nurses of the $16 \mathrm{~N}-\mathrm{HUECU}$ in the metropolitan region of Campinas working on the day shift ( 8 hours), morning and afternoon ( 6 hours), and night shift (12 hours) from August to October 2007.

Data were collected through a questionnaire divided into parts: the first characterized the nurses (identification, professional background, characterization of work, BLS and ALS training programs, and updates on CPA and (PR) and the second part addressed the knowledge of nurses concerning CPA and CPR. This questionnaire was based on the instrument developed by Bellan(4), adapted according to the guidelines of the 2005 International Consensus of Cardiopulmonary Resuscitation and Emergency Cardiovascular Care Science $^{(5)}$. It was submitted to a new validation process due to this update and included open and closed questions. Authorization was asked of the Health Departments of the metropolitan region of Campinas that had N-HUECU, after the Ethics Research Committee at the university approved the project (protocol no 817/2006).

The questionnaire was individually applied during all the shifts in each of the units according to the nurses' work schedules in the presence of one of the researchers after the participants signed free and informed consent forms. Data were entered into Excel spreadsheets and descriptive and comparative analyses were performed using the Mann-Whitney and Kruskal-Wallis tests. Spearman's correlation was used in the analysis of scores obtained for the knowledge evaluation in relation to the numerical variables. The level of significance was set at $5 \%$.

\section{Results}

The sample was composed of 73 (80.2\%) individuals. Three $(2.7 \%)$ of the nurses refused to participate, eight (7.3\%) were on vacation or sick leave, six worked in two different N-HUECU and one worked in three different N-HUECU, thus, they answered the questionnaire only once.

Table 1 - Distribution of socio demographic variables, work shifts and professional update training of nurses with post-degree and training programs from the $\mathrm{N}$-HUECU in the metropolitan region of Campinas. Campinas, Brazil, 2007

\begin{tabular}{|c|c|c|}
\hline Variables & $\mathbf{n}$ & $\%$ \\
\hline \multicolumn{3}{|l|}{ Gender } \\
\hline Female & 59 & 80.8 \\
\hline Male & 14 & 19.2 \\
\hline \multicolumn{3}{|l|}{ Age } \\
\hline$<30$ & 22 & 30.1 \\
\hline $30-39$ & 27 & 37.0 \\
\hline $40-49$ & 17 & 23.3 \\
\hline$\geq 50$ & 07 & 9.6 \\
\hline \multicolumn{3}{|l|}{ Post-degree programs } \\
\hline Specialization & 52 & 71.2 \\
\hline Master's degree & 01 & 1.4 \\
\hline None & 20 & 27.4 \\
\hline \multicolumn{3}{|l|}{ Work shift } \\
\hline Morning & 03 & 4.1 \\
\hline Afternoon & 03 & 4.1 \\
\hline Day & 39 & 53.5 \\
\hline Night & 28 & 38.3 \\
\hline \multicolumn{3}{|l|}{ Training programs } \\
\hline BLS & 17 & 23.3 \\
\hline ALS & 04 & 5.5 \\
\hline $\begin{array}{l}\text { Some kind of update training (books. periodicals. } \\
\text { lectures, training) in CPA }\end{array}$ & 48 & 65.8 \\
\hline No update training in CPA & 25 & 34.2 \\
\hline \multicolumn{3}{|l|}{ Cities } \\
\hline A & 04 & 5.5 \\
\hline B & 08 & 11.0 \\
\hline $\mathrm{C}$ & 04 & 5.5 \\
\hline $\mathrm{D}$ & 03 & 4.1 \\
\hline $\mathrm{E}$ & 13 & 17.8 \\
\hline $\mathrm{F}$ & 11 & 15.1 \\
\hline G & 30 & 41.0 \\
\hline
\end{tabular}

There is a predominance of the female gender $(80.8 \%)$ among 30 and older than 50 years of age $(37 \%)$. The average age was $36.2( \pm 9.2)$ years old, and the median was 35 years old. The universities 
most frequently reported by the nurses were those in the interior of the state of São Paulo. Most (71.2\%) of the individuals had attended post-degree programs. Of these, some had one or more specializations and the most frequently reported fields were: Family Health (11/73), Intensive Care Unit (8/73), occupational nursing and obstetrics (7/73 each), Hospital Administration (6/73), Public Health and Pre-hospital Care (5/73 each).

Most $(53.5 \%)$ of the study's participants worked during the day shift (Table 1) and there were no nurses in some N-HUECU working during the night shift. A total of $23.3 \%$ of nurses had attended BLS and $5.5 \%$ had attended ALS training programs.

The BLS training programs were taken on average three years and 10 months prior and the ALS programs three years prior. In relation to updated training in CPA/ CPR, $65.8 \%$ reported some kind of activity: reading books and periodicals, attending lectures, training programs or workshops, which had occurred on average one year and half prior (Table 2).

Table 2 - Presentation of variables: time since graduation, time working in the unit, time working in similar unit, experience in performing BLS/ALS and time since last updated training in CPR of nurses of $\mathrm{N}-\mathrm{HUECU}$ in the metropolitan region of Campinas, Brazil - 2007

\begin{tabular}{lcccc}
\hline \multicolumn{1}{c}{ Variables } & $\mathbf{n}$ & $\begin{array}{c}\text { Average (in } \\
\text { months) }\end{array}$ & SD & $\begin{array}{c}\text { Average (in } \\
\text { months) }\end{array}$ \\
\hline Time since graduation & 73 & 77.3 & 68 & 48 \\
Time working in the unit & 73 & 23.5 & 31.4 & 9.5 \\
Experience in BLS & 17 & 47.1 & 38.8 & 36 \\
Experience in ALS & 4 & 37 & 40.5 & 24 \\
Time since update in CPR & 25 & 17.8 & 14.9 & 12 \\
\hline
\end{tabular}

In relation to the frequency with which nurses provided care in situations involving CPA, 50.7\% of the nurses reported this was a frequent event, while $34.3 \%$ reported it was a rare event and $15.1 \%$ very rare.

Table 3 - Distribution of answers of nurses of in the metropolitan region of Campinas concerning theoretical knowledge of CPA/CPR. Campinas, Brazil, 2007

\begin{tabular}{|c|c|c|c|c|}
\hline \multirow[b]{2}{*}{ Type of questions } & \multicolumn{4}{|c|}{ Answers (\%) } \\
\hline & Correct & Partially correct & Incorrect & Total \\
\hline A - Detection of CPA & 38.4 & 61.6 & - & 100 \\
\hline $\mathrm{B}$ - Immediate procedures after CPA & 24.7 & 67.1 & 8.2 & 100 \\
\hline C - Rhythm patterns in CPA & 12.3 & 49.3 & 38.4 & 100 \\
\hline D - Sequence of BLS & 32.9 & - & 67.1 & 100 \\
\hline E - Body posture of the rescuer during external chest compression & 20.6 & 46.6 & 32.8 & 100 \\
\hline $\mathrm{F}-$ Compression to ventilation ratio & 37.0 & - & 63.0 & 100 \\
\hline G - Position of defibrillation paddles & 74.0 & - & 26.0 & 100 \\
\hline $\mathrm{H}$ - Power joules used in defibrillation & 31.5 & - & 68.5 & 100 \\
\hline I - Of what does ALS consist? & 9.6 & 45.2 & 45.2 & 100 \\
\hline $\mathrm{J}-$ Routes of drug administration & 16.4 & 76.7 & 6.9 & 100 \\
\hline $\mathrm{K}-$ What are the drugs used in CPA? & 0.0 & 100.0 & - & 100 \\
\hline$L$ - Purpose of drugs & - & 52.0 & 48.0 & 100 \\
\hline$M$ - Nursing certification in CPA & 20.6 & 71.2 & 8.2 & 100 \\
\hline
\end{tabular}

A total of $38.4 \%$ of the answers presented in Table 3 regarding the topic $\mathrm{A}-$ Detection of CPA-were correctly answered by nurses, while $61.6 \%$ were partially correct; the least checked alternative among those considered correct was the one that mentioned unconsciousness.

In relation to the procedures performed immediately after the CPA diagnosis (topic B), the least checked alternatives in partially correct answers (67.1\%) were those related to requesting help and the emergency cart with the defibrillator.

In relation to the cardiac rhythms found in CPA (topic C), only $12.3 \%$ of nurses answered correctly; the answers of $49.3 \%$ were partially correct and of $38.4 \%$ of them were incorrect. The least checked alternatives among those considered correct were: pulseless ventricular tachycardia, ventricular fibrillation, and pulseless electrical activity.
A total of $67.1 \%$ of the nurses incorrectly answered the question related to the sequence recommended for BLS (topic D), that is, these individuals do not know the BLS guidelines.

In regard to the body posture recommended during external chest compression (topic $\mathrm{G}$ ), the individuals did not check the alternative related to the rescuer's arms position (which should form an angle of 90 degrees in relation to the patient's chest) in the partially correct answers (46.6\%).

When asked about the compression-ventilation ratio (topic F), 63\% of the respondents revealed lack of knowledge concerning this topic; only $37 \%$ answered it correctly. Most of the individuals checked the 15:2 ratio.

Most (74\%) of the participants correctly answered the question addressing the correct position of the 
paddles during defibrillation (topic G). Nevertheless, the question concerning the power load required for monophasic defibrillation (topic $\mathrm{H}$ ) obtained the highest number of incorrect answers (68.5\%); the alternative most checked among those considered incorrect was 200 joules.

The percentage of correct answers in the question concerning ALS (topic I) was low (9.6\%); the answers partially correct and incorrect totaled $45.2 \%$. The items in this question that recommended early defibrillation, the use of equipment for oxygenation and ventilation, cardiac monitoring, obtaining and maintaining venous access, and implementing medication were not checked.

For the potential routes for the administration of medication during CPA (item J), the individuals did not check the alternative that indicated intraosseous route and, therefore, $76.7 \%$ of the questions were only partially correct.

The question addressing the medication used during CPA (item K) obtained $100 \%$ of partially correct answers while the least checked alternatives were those related to vasopressin, lidocaine, calcium and amiodarone.

In regard to knowledge concerning the purpose of medication (item L), $65.7 \%$ of the respondents reported knowledge concerning its purpose, however, the answers of $52 \%$ were partially correct. The bestdescribed medications were adrenaline (65.7\%) and atropine $(54.8 \%)$.

The least checked alternative in the partially correct answers concerning the question addressing nursing records on care provided during CPA (item $M$ ) was the one that required the nurse to note the type of CPA $(20.7 \%)$.

Overall, the mean score obtained by nurses was 6.7 $( \pm 1.8)$ out of 13 , the total score they could obtain, with a minimum of 2.3 and a maximum of 11.7 . Converting these scores to grades from zero to ten, the average grade obtained by the nurses working in N-HUECU of the Metropolitan Region of Campinas was $5.2( \pm 1.4)$, with a minimum of 1.8 and maximum of 9.0.

When the total scores obtained by gender were compared, we observed that the median score of male nurses was higher than that obtained by female nurses $(p=0.011$, Mann-Whitney test). Differences were also found between genders in the medians of questions concerning detection of CPA $(p=0.018)$, ALS $(p=0.013)$, medication in CPA $(p=0.012)$ and the question concerning nursing records $(p=0.013)$.

Another result found was a significant difference between the scores of the individuals who attended BLS training programs $(n=17)$ and those who did not $(n=56)(p=0.015)$, including particularly the questions addressing cardio rhythms in CPA $(p=0.007)$ and BLS $(p=0.046)$. No differences were found in the scores obtained concerning theoretical knowledge of those who attended $(n=4)$ and who did not attend an ALS training program $(p=0.146)$. Nevertheless, differences were found in the scores related to the theoretical knowledge of individuals who pursued update training in CPA in relation to those who did not $(p=0.045)$.

Association between the variables 'time since graduation' and 'compression to ventilation ratio during $C P R^{\prime}$ indicated that the longer the time since graduation the lower the nurses' theoretical knowledge ( $r=-$ 0.24524 ; Spearman's correlation coefficient $p=0.0365$ ). Similarly, the longer the time since updating one's training, the lower one's knowledge concerning body posture required during external chest compressions $(r=-0.41483 ; \quad p=0.0392)$. Another association revealed that the older the individual the lower one's knowledge concerning the appropriate power load used in defibrillation ( $r=-0.24942 ; p=0.0333$ ).

The comparative analysis of scores on knowledge concerning CPA/CPR of nurses of different cities did not display significant differences $(p=0.329 ;$ Kruskal-Wallis test) as presented in Table 4. Hence, the performance of nurses was equivalent.

City $\mathrm{G}$ presented the best performance followed by $D, B, F$ and A (Table 4). The nurses who presented the lowest average scores were those in the cities $C$ and E. However, when city $G$ (with the largest number of nurses) was compared to the other cities, a significant difference was found mainly in relation to procedures performed immediately after CPA is detected $(p=0.040)$; CPA rhythms $(p=0.010)$; and knowledge concerning ALS $(p=0.019)$. Although, according to the Mann-Whitney test, the total average scores were not significantly different between city $G$ and the others $(p=0.105)$.

Table 4 - Distribution of nurses' scores concerning theoretical knowledge of CPA/CPR in the metropolitan region of Campinas, Brazil, 2007.

\begin{tabular}{|c|c|c|}
\hline Cities & $\mathrm{n}$ & Average grade \\
\hline$A$ & 4 & 5.16 \\
\hline$B$ & 8 & 5.29 \\
\hline C & 4 & 4.15 \\
\hline D & 3 & 5.50 \\
\hline$E$ & 13 & 4.50 \\
\hline $\mathrm{F}$ & 11 & 5.26 \\
\hline G & 30 & 5.52 \\
\hline
\end{tabular}

Kruskal-Wallis test $(p=0.329)$ 


\section{Discussion}

This study indicated that the nurses' average time since last receiving update training was 18 months, a fact falling short of what is recommended in the literature, that knowledge should be updated every six months for one to maintain knowledge and skills in the urgent/ emergency field ${ }^{(4,6)}$. There is a concern related to these professionals' continuing qualifications.

The results of this study related to CPA update training is of concern because we know that the less frequent one updates knowledge the lower one's retention of knowledge/skills ${ }^{(7-8)}$. Some aspects should be reviewed and updated to ensure improved performance and quality care, especially because updates should be constant, since theoretical knowledge and skills tend to decline over time ${ }^{(9-10)}$

According to one study(10), only $42 \%$ of nurses require help, a finding similar to that of this study $(36.8 \%)$. It is important to note that procedures to reestablish the health of patients are initiated earlier with the help of the team(11).

Almost $70 \%$ of the nurses in this study had difficulty listing the sequence of procedures required in $B L S$. However, the primary $A B C$ sequence ( $A$ - Airway, $B$ - Breathing, $C$ - Circulation) has been emphasized in literature $^{(12)}$ for years. More recently, defibrillation (D) was added to the primary $\mathrm{ABCD}^{(13)}$.

The results in relation to the rescuer's body posture during external chest compressions are of concern because this is a procedure that should be performed in the correct position and reach 100 compressions/minute to be effective in taking medication and oxygen to vital $\operatorname{organs}^{(13)}$.

It is interesting to note that the compression to ventilation ratio $30: 2^{(3,5)}$ is known by only $37 \%$ of nurses, while most of them responded that the appropriate ratio is $15: 2$, according to previous guidelines ${ }^{(14)}$. This fact reinforces the need for training programs and updating. The same occurred in relation to the power load used in defibrillation; the most frequent answer for this item was 200J, which is according to the 2000 guidelines $^{(15)}$.

Of the drugs most frequently used during CPR, the least mentioned were vasopressin, lidocaine, amiodarone and calcium. More than $60 \%$ of the respondents reported knowledge concerning the purpose of these medications, however no one was able to describe all the purposes, which suggests that nurses are concerned in correctly administering the medications but are unaware of their pharmacological actions ${ }^{(4)}$.
In regard to the nursing record related to CPA/ $\mathrm{CPR}$, the item 'type of CPA' was seldom mentioned. It is important to note that currently there are protocols for recording the CPR procedure. A form has been developed and validated at a national level aiming to obtain concise but complete information to accurately describe what happened to the patient at the time of CPA/CPR, which also serves as a legal document(16).

The performance of nurses in the theoretical test presented results similar to those found in another study in which physicians displayed deficiencies in theoretical knowledge concerning resuscitation and whose average knowledge score was $54.5 \%{ }^{(17)}$. A recent study revealed that nurses presented an average of 6.8 correct answers before training; about $60 \%$ of them correctly answered more than $75 \%$ of the questions ${ }^{(18)}$.

The author of another study ${ }^{(7)}$ reported that only $6 \%$ of nursing students achieved the minimum required to be approved concerning the topic of resuscitation. However, after theoretical-practical training, this proportion rose to $72 \%$. The scores found by other authors concerning CPA/CPR knowledge were $50.3 \%$ pre-training and $60.5 \%$ post-training $(p<0.001)$, confirming that training should be periodically administered. A recent national study corroborates these findings and reveals that $90 \%$ of the studied professionals achieved satisfactory level of knowledge after a training program(18).

A study conducted in Mexico in the 1980s addressing the knowledge of physicians and nurses who received formal training, no training, and informal training indicates that groups without training and with informal training correctly answered $64 \%$ of the items, while the formally trained group correctly answered $77 \%(20)$. A total of $2.4 \%$ of the physicians evaluated in another study conducted in Ecuador in the 1990s failed a test addressing knowledge concerning ALS; these individuals wrongly answered all the 10 questions concerning $\mathrm{CPR}^{(21)}$.

Significant differences were found in this study in relation to the median scores of males (5.8) and females (4.9) $(p=0.011)$. Differences between genders were also found in relation to detection of CPA, ALS, medication used and nursing records. These findings are similar to another study ${ }^{(17)}$ in which the average score for men was 11.4 and for women was $12.3(\mathrm{p}<0.05)$. Data explaining such differences were not found in the literature.

Other differences found were related to the median scores of those who attended BLS training (5.7) and of those who did not (4.9), including questions that addressed rhythms and BLS sequence. These results 
indicate that professionals who attend a BLS program are able to list the sequence of procedures without difficulty. No differences, however, were found in the scores of those who attended ALS and those who did not, although few individuals in this study took part in such a program.

This information shows the importance of basic and advanced life support programs. Another study ${ }^{(17)}$ indicates that the score of emergency physicians who attended an ALS program was 14.9 while the score of those who did not was 10.5. These results are similar to those found in another study (22), where the group with BLS presented improved performance. Another study ${ }^{(23)}$ shows that the survival of patients cared for by nurses who had attended ALS programs were almost four times higher compared to those cared for nurses who had not attended such programs. The chance of success and CPA reversion is twice as high if there is an individual with ALS training in the team ${ }^{(24)}$.

This study also showed differences of knowledge among those who made some kind of updating in CPR $(p=0.045)$, congruent with another finding ${ }^{(25)}$ in which $53 \%$ of the participants had attended update training programs in the last six months and the nurses who had attended such programs less than six months ago displayed better performance in CPA/CPR simulations. Another study(11) stresses that despite the fact that $64 \%$ of the studied nurses had attended update training programs, their theoretical knowledge was still insufficient in the face of international consensus.

Data from this study suggest that the longer the time since graduation the lower one's theoretical knowledge concerning compression to ventilation ratio and electrical load used in defibrillation, which justifies the need for professionals to update their knowledge to keep track with periodic changes triggered by advances in research in the field.

No differences were found concerning the theoretical knowledge of nurses on CPA/CPR among cities. The average grade in the largest city with the highest number of nurses was 5.5. These nurses displayed the highest level of theoretical knowledge concerning procedures taken immediately after CPA detection, cardiac rhythms and ALS. However, no statistically significant differences were found in the comparison between the scores of nurses from the largest city and the other cities. This fact is of concern because this city has nine nursing schools in addition to centers of acknowledged excellence in research and teaching, which would, in theory, favor access to update training and BLS and ALS programs that occur periodically. Nevertheless, the performance of the professionals from this city was not satisfactory.

\section{Conclusion}

It was possible to conclude that the nurses working in the N-HUECU of the metropolitan region of Campinas, $\mathrm{SP}$, Brazil have insufficient theoretical knowledge concerning $C P A / C P R$, since the average grade obtained was $5.2( \pm 1.4)$ out of 10 , that is, they correctly answered $50 \%$ of what is required.

This study revealed that there are not many differences in terms of knowledge among the nurses in the metropolitan region of Campinas, though those in city $\mathrm{C}$ presented the worse scores.

Given this study's results, the need for qualification and update training programs is apparent so that nurses can acquire improved theoretical knowledge and consequently improve their performance, contributing to patient survival.

This study contributes to the dissemination of results concerning theoretical knowledge of nurses working in the non-hospital scope since existing studies focus on results from nurses working either in hospitals or mobile pre-hospital care.

\section{References}

1. Ministério da Saúde (BR). Portaria n.o 2048/GM, de 5 de novembro de 2000. Regulamento técnico dos sistemas estaduais de urgência e emergência. Brasília; 2002.

2. Horsted T, Rasmussen LS, Meyhoff CS, Nielsen SL. Long-term prognosis after out-of hospital cardiac arrest. Resuscitation. 2007;72:214-8.

3. Dalri MCB, Araújo IEM, Silveira RCCP, Canini SRMS, Cyrillo RMZ. Novas diretrizes da ressuscitação cardiopulmonar. Rev. Latino-Am. Enfermagem. 2008 dezembro; 16(6):1060-2.

4. Bellan MC. Capacitação do enfermeiro para o atendimento da parada cardiorrespiratória. [Dissertação]. Campinas (SP): Faculdade de Ciências Médicas/Universidade Estadual de Campinas; 2006.

5. Guidelines 2005 for cardiopulmonary resuscitation and emergency cardiovascular care. International consensus on science. Part 1. Introduction to the Guidelines for CPR and ECC. A consensus on science. Resuscitation. 2005;46:3-16.

6. Woollard $M$, Whitfield $R$, Smith $A$, Colquhoun $M$, Newcombe RG, Vetter $N$, et al. Skill acquisition and retention in automated external defibrillator (AED) use and CPR by lay responders: a prospective study. 
Resuscitation. 2004;60(1):17-28.

7. Madden C. Undergraduate nursing students' acquisition and retention of CPR knowledge and skills. Nurs Ed Tod. 2006; 26:218-27.

8. Nikandish R, Jamshidi $H$, Musavifard R, Zerbardast $T$, Habibi N. Basic cardiopulmonary resuscitation skills of nurses at a teaching hospital in Southeast Iran in 2006. Resuscitation. 2006;73:321-2.

9. Hamilton R. Nurses' knowledge and skill retention following cardiopulmonary resuscitation training: a review of the literature. J Adv Nurs. 2005;51(3):288-97.

10. Miotto HC. Fatores envolvidos na fixação do aprendizado durante os cursos de suporte avançado de vida em cardiologia. [Dissertação]. Belo Horizonte (MG): Universidade Federal de Minas Gerais; 2007.

11. Galinski M, Loubardi N, Duchossoy MC. In-hospital cardiac arrest resuscitation: medical and paramedical theory skill assessment in an university hospital. Ann Fr Anesth Reanim. 2003;22(3):179-82.

12. Silva AR. Parada cardiorrespiratória em unidades de internação. Vivências do enfermeiro. [Dissertação]. Ribeirão Preto (SP): Escola de Enfermagem de Ribeirão Preto/Universidade de São Paulo; 2006.

13. American Heart Association (AHA). Inc. Part III: Overview of CPR. Circulation. 2005;112(24):12-8.

14. Guidelines 2000 for cardiopulmonary resuscitation and emergency cardiovascular care. International consensus on science. Part 3. Adult basic life support. Resuscitation. 2000;46:29-71.

15. Guidelines 2000 for cardiopulmonary resuscitation and emergency cardiovascular care.International consensus on science. Part 6. Advanced cardiovascular life support. Resuscitation. 2000;46:109-62.

16. Boaventura AP, Araújo IEM. Registro do atendimento da parada cardiorrespiratória no ambiente intrahospitalar: aplicabilidade de um instrumento. Rev Gaucha Enferm. 2006;27(3):434-42.

17. Filgueiras NMF, Bandeira AC, Delmondes T, Oliveira A, Lima ASJ, Cruz V, et al. Avaliação do Conhecimento geral de médicos emergencistas de hospitais de Salvador - Bahia sobre o atendimento de vítimas com parada cardiorrespiratória. Arq Bras Cardiol. 2006;87:634-40.

18. Brião RC, Souza EN, Castro RA, Rabelo ER. Estudo de coorte para avaliar o desempenho da equipe de enfermagem em teste teórico, após treinamento em parada cardiorrespiratória. Rev. Latino-Am. Enfermagem. 2009 jan-fev;17(1):40-5.

19. Boonmak P, Boonmak S, Srichaipanha S, Poomsawat S. Knowlegde and skill after brief ACLS training. J Med Assoc Thai. 2004;87(11):1311-4.
20. Wheatley LL, Pérez ET, Macías AS. Estado actual de la reanimatión cardiopulmonar em Monterrey, Nuevo León, México. Arch Inst Cardiol Méx. 1988;58(3):237-41.

21. Toapanta EP, Troya ME, Córdova G. Conocimiento médico sobre reanimatión cardiopulmonar. Rev Med Cient. (Quito) 1997;9:71-6.

22. Ribeiro EP. Avaliação do ensino, treinamento e aprendizagem em ressuscitação cardiopulmonar dos residentes médicos e de enfermagem de um hospital de ensino. [Tese em Cardiologia]. São Paulo (SP): Escola Paulista de Medicina/Universidade Federal de São Paulo;2004.

23. Dane FC, Russell-Lindgren KS, Parish DC. In-hospital resuscitation: association between ACLS training and survival to discharge. Resuscitation. 2000;47:83-7.

24. Moretti AM. Eficácia do treinamento em suporte avançado de vida nos resultados das manobras de ressuscitação cardiopulmonar. [Tese Doutorado]. São Paulo (SP): Faculdade de Medicina da Universidade de São Paulo;2002.

25. Nyman J, Sihvonen M. Cardiopulmonary resuscitation skills in nurses and nursing students. Resuscitation. 2000;47:179-84.

Received: Dec. $12^{\text {th }} 2009$ Accepted: Oct. $21^{\text {st }} 2010$ 